\title{
Goat Days: A Study in Existentialism
}

\author{
Jasmine Fernandez \\ St. Ann's Garden, Convent Road Tangassery
}

\begin{abstract}
This paper attempts to explore the existential crisis of the protagonist, Najeeb, in Benyamins' 'Aadu Jeevitham' (Eng: translated: Goat Days - Joseph Koyippally). It aims in analyzing his crisis on the basis of economic and social aspects and his perception as a 'human being', which reflects the basic theme of existentialism. Here Najeeb is in an existential crisis because he is alien to the land and his new to the profession of a shepherd, tending goats in a desert land. He has no kindred and feels his life meaningless and absurd-his consciousness and awareness of his life as nothing as he has no choice. The absurdity of his life, aloofness and despair all are caused by fate.
\end{abstract}

\section{Introduction:}

"Existentialism is a term applied to the work of certain late $19^{\text {th }}$ and $20^{\text {th }}$ century philosophers who despite profound doctrinal differences shared the belief that philosophical thinking begins with the human subject - not merely the thinking subject, but the acting feeling, living human individual." (John Macquaire)

In existentialism the character has a sense of disorientation, confusion in the face of an apparently meaningless or absurd world. Soren Kierkegaard is generally considered to have been the first existential philosopher, but the term was however coined by the French philosopher Johan Sebastian Gabriel Marcel in the mid 1940's.

Kierkegaard proposed that" each individual - not society or religion - is solely responsible or giving meaning to life and living in passionately and authentically."(Kierkegaard)

The roots of existential thought can be traced in the philosophy of Soren Kierkegaard (1813-1855) Friedrich Nietzsche (1844-1900), Albert Camus (1913-1960), Martin Heidegger (1889-1976), Karl Jespers (1883-1969) and Jean Paul Sartre (1905-1980).

They aim to rouse the individual consciousness to an awareness of his own existence, freedom and choice. Just as Kierkegaard quotes "My whole life is an epigram calculated to make people aware."

Existentialism became popular in the years following the world war II and strongly influenced many disciplines besides philosophy including theology, dance, art, literature and psychology.

Sartre purports the idea that "all existentialist have in common is the fundamental doctrine that existence precedes essence."

The central proposition of existentialism is that existence precedes 'essence' This means that most important consideration for an individual is the fact that he or she is an independent individual existing and responsible conscious being, rather than what labels, roles, stereotypes, definitions or their pre conceived categories the individual fits. The actual life of the individual is called his "true essence." Thus human beings, through their own consciousness, create their own values and determine a meaning to their life.

"Sartre writes in his work Existentialisms in Humanism." Man first of all exists, encounters himself, surges up in the world - and defines himself afterwards." The second major notion is that of absurd -the idea that there is no meaning in this world. The main focus of existentialism is:

$\begin{array}{ll}\text { i. } & \text { Freedom and freewill } \\ \text { ii. } & \text { Responsibility } \\ \text { iii. } & \text { Choice } \\ \text { iv. } & \text { Despair } \\ \text { v. } & \text { Alienation } \\ \text { vi. } & \text { Social isolation } \\ \text { vii. } & \text { Absurdity } \\ \text { viii. } & \text { Anxiety } \\ \text { ix. } & \text { Meaninglessness \& nothingness } \\ \text { x. } & \text { Normallessness of traditional values }\end{array}$

Najeeb as an existentialist

The Goat Days by Joseph Koyippally endeavours to create an existentialist out of Najeeb, the narrator by making him feel life as meaningless. It is a story of rootlessness, meaninglessness and absurdity in the life of 
Najeeb the narrator as he is accidently placed in a wrong profession in a foreign land (the Gulf). His identity is demolished and he lives the 'life of a goat,' until his return to his native land where he gets back to himself.

Najeeb a young Malayalee from Karuvatta, travels to the Gulf region on a job visa. However in his native land he was a worker in the river mining where suddenly the regulations to stop sand mining came up and there was a chance for the workers to become jobless.

There was a rumor that sand mining was going to be regulated. If that too is gone, what work can I get? Can one go hungry?" (pg 35)

The situation coupled with a chance to work abroad turned him to get a visa from a friend in Karuvatta. "When a friend from Karuvatta casually mentioned there was a job visa for sale, I felt a yearning I had never experienced before."(pg 35)

Mortgaging his house, wife's jewelry and taking loans from sand mining community Najeeb made his dream come true.

"Some situations in our lives are even more absurd that a film scene. Isn't that so?" (39)

Thinking back about all the events made him feel that the situation was absurd and meaningless. He was happy that all those days are gone by.

Fate played a major role in making Najeeb's life meaningless, absurd and nothing. A wrong Arab had forced him at the international airport at Riyadh.

'Abdullah?' He pointed his finger at my friend Hakeem and me. I had never heard such a crude voice before. I shook my head. (pg 47)

Leaving us there, he went around the airport again. From time to time he would grab the passport of anyone who stood alone and look at it. Finally he came back to us. Then he snatched my passport and looked into it. Then without saying a word he walked forward carrying our bags we followed him.(pg 48)

Finally we were at the back of a carrier van which had huge tins of grass and the Arbab was seated at the wheel. They travelled for hours away from the city.

"From that moment, like the maniyan fly, an unknown fear began to envelop my mind. An irrational doubt began to grip me, a feeling that this journey was not leading me to the Gulf life that I had been dreaming about and craving for. The Gulf I had learned from so many people was not like this." (pg 52)

Finally they reached a place in pitch darkness. "I sensed that we reached a plain with not a building or tree anywhere in sight. Far away, like some map, some mountains or hills silhouetted against the dark sky, could be seen. A cry sprung up my heart: My Lord, where have I ended up?" (pg 55)

Najeeb along with his friend ended up in two different places as directed by the arbab. He felt lonely in a queer land. The only thing he could discern was a foul stench from the place. Then he was handed to a arbab from the tent close by. The he left him by the front of an iron gate. He finally realized he was amidst hundreds of goats.

"Then, as if to acknowledge my presence, I heard a light whimper. It was the bleat of a goat. I peered inside the fence. Goats! Hundreds of goats! Rows of goats; undulating like sea. It struck me like a thunderbolt. I had a rough idea of my job now." (pg 59)

Najeeb felt shattered and disoriented. He understood that he would become insane like his companion there in the tent.

"I was waiting 'I have to go', 'I cannot be here.' I did not come for this work. Although I knew that the arbab didn't understand a thing, I felt it my duty to say what I had to say.” (pg 66)

Najeeb was initiated into the world of the shepherd, given his typical dress of the Saudi Arab man and his staff for tending the goats. He also 'realized his life was inescapably bound to the goats'(pg 73)

Casting off the previous night's thoughts of escape, I walked into the desert. I remember: it was only sheer emptiness that filled me then. (pg 74)

Loneliness and a feeling of emptiness filled him as he felt completely out of place. He knew it was not his place. The unexpected profession made him to crave for home. He was not used to a shepherd's life. He felt rootless, for place was so different.

"Unlike in our place, where vines spread through rocks and sand, there was not a speck of green here. It was sterile waste land." (pg 74)

Even for doing his daily rituals, he had nowhere. There was no privacy or water available. It was totally an alien feeling. It was totally a new experience to use minimum water and not only that to remain unwashed for two days.

"After, that for a brief while, it was rest time. I searched all around for a little shade, but it was nowhere to be found." (pg 81)

For one who would have lived in the comfort of a home and slept in the luxury of a bed, sleeping openly on the sand, with the light of the sun falling directly on the face was terrible and unbearable and for an existentialist, geographical displacement matters a lot. 
"Again, I noticed - I had started noting new things with my eyes and mind - that the little lamb were not kept with their mothers." (pg 83)

After a brief period of training Najeeb, the scary figure escaped from the masara one night. Now he was left alone once again without human companionship.

"A few words were all that we had exchanged .... Still it found a lot when I realized he had gone. I couldn't fathom the reason for the pain. It might have originated from the anguish of intense loneliness." (pg 99)

He cursed his life of loneliness and he hated this work.

"The scary figure got his freedom. My reward: back breaking labour! A lash that I would never forget. Starvation till lunch!” (pg 103) human being.

He longed for his freedom, the freedom to be himself, to eat some food at proper time and be a happy

"I was learning to face life alone, to train myself in jobs I had never performed before, to try out a new way of life, to get accustomed to an uncommon situation. It was not as if I had a choice; I was utterly helpless." (pg 104)

His continuous stay with the goats made him feel that goats understood me better than arbab ever did.

His sense of alienation was so high that he felt he was not on Earth.

"I lived on an alien planet inhabited by some goats, my arbab and me." (pg 125)

He felt so lonely that the sight of human beings brought him great joy.

"My heart would flutter with inexpressible joy whenever those vehicles reached the masara I'd be elated as if some loved ones had come to visit us. I would chat with the goats more than usual. But when those vehicles raising dust faded away, I felt like the world itself had run away from me. Then a heart draining fatigue would come over me." (pg 126)

Najeeb tried his best to convey his misery to the only human species that arrived for loading and unloading grass. However he could only read an icy coldness in their face.

"The anguish I felt when the arbab had called me to the trailer, I had run to him with so much hope, deserting the goats. It was an optimistic dash towards the light of life. But the driver's cold look drained me all hope." (pg 126)

He lost his hope to get help from the driver and anxiety filled him to meet him. However the cold behavior once again made him lonely, aloof and heartbroken.

He could not even meet his friend who came with him on the first day. He thought that he would meet the Hakeem, who was also facing the same plight in the neighbouring masara.

"The poor boy was so near yet so far. It was only then that I registered the extent of my cocooned existence." (pg 135) "I spent the winter as a sheep among the sheep." (pg 140) "I didn't have enough food, water, clothes, a proper place to sleep, wages, dream or aspiration. But I did have something precious left - my life." (pg 141)

One day when the winter was coming to an end two men came to shear the sheep. They were Sudanese and both of them had broad smiles.

"Filled with the joy of meeting people after a long time I followed them around like a puppy." (pg 142)

Once the shearing was over and the two men left in a truck, he felt lonely once again.

"The sense of dejection descended on me as they departed. I had been enjoying the scent of two humans till then. Now there was only animals and me. Grief came like rain." (pg 143)

Again memories of homeland awakened in him. All his suppressed feelings came alive and thought to gain freedom caught his brain. Najeeb tried to escape but his arbab had caught sight of him and fired at him but an innocent he-goat was killed instead of him. He was returned with more torture and again back to his duty as shepherd. His punishment of starvation for two days for not eating the meat of the goat which got killed, forced him to eat "raw wheat, unhusked with some salt and he finally became a goat.

During the harsh summer, "his fervent desire was to sit in a bit of shade for some time." (pg 151)

He even prayed to Allah to send a saviour to liberate him from this captivity. However he had no option but to stay there and it was always fate that made him a shepherd and gave no chance of escape until the right time.

Finally he escapes with Hakeem and Khadiri the new coworker Hakeem. The final fleeing away from the masara was a personal choice and as an existentialist, this helped him to regain his identity as Najeeb - the human once again.

Conclusion

Najeeb is an existentialist because of his alienated behavior, his being an outsider in an alien society and his exile from the masara, from the absurdity of his meaningless life as a goat, his constant conflicts and consciousness about the nothingness of his existence and his rejection of the goats' life forever. Najeeb is a seeker of his identity, freedom and meaning in life. For him his native land, his society is the ultimate meaning of his life. Therefore he flees and finally returns to Kerala his homeland. 


\section{Bibliography:}

[1]. Benyamin, Goat Days. Trans, Joseph Koyippally, India: Penguin, 2012.

[2]. Kierkegaard, Soren. Papers \& Journals: A Selection 1835 - 1854. London: Penguin, 1996.

[3]. Macquaire,John. Existentialism.NewYork, 1972.(1-2)

[4]. Sartre J.P. ,Existentialism and Humanism.London:Trans, Philip Nairet, Methuen \& Co, 1970. 